\title{
Genetic Causes of Syndromic and Non-Syndromic Congenital Heart Disease
}

\author{
Akl C. Fahed and Georges M. Nemer \\ Additional information is available at the end of the chapter
}

http://dx.doi.org/10.5772/48477

\section{Introduction}

Congenital heart disease (CHD) is the most common human congenital defect, and a leading cause of death in infants. With an incidence that varies between 0.8 to $2 \%$ in neonates, congenital heart disease contributes to a much larger fraction of stillbirths.(Goldmuntz 2001; Loffredo 2000) Additionally, undiagnosed mild malformations of the heart often appear later in adulthood or remain undiagnosed for life. If these are included, some expect a prevalence of CHD that is up to $4 \%$ among all newborns.(Loffredo 2000) An additional contributor to the rising prevalence of CHD among adults is the advance in diagnostics and medical and surgical treatments of children with CHD, which is allowing them, in the majority of cases, to get their heart defect, fixed and sustain a normal life into adulthood.(van der Bom and others 2011) Management of the increasing number of adult patients living with CHD is becoming more and more complicated due to the fact that many patients with mild cardiac lesions are missed during childhood and later appear with complications due to these defects such as heart failure, but even more due to the improvements in diagnosis and surgical care of pediatric patients which are allowing them to survive to adulthood and have their own children.

The majority of CHD is thought to result from gene mutations. This was suggested by early observations of Mendelian inheritance of CHD in families. Another evidence came from congenital syndromes due to micro and macro deletions of chromosomal regions that would result in CHD together with several other manifestations. Over the past few decades, and with the advent of gene sequencing and other techniques it became possible to identify the genetic causes of CHD.(Goldmuntz 2001) In syndromic cases, although it was possible to identify the chromosomal deletions causing the disease, in many cases the gene responsible for the heart phenotype remains undefined. Other syndromes were found to be due to single gene defects; however, for the majority, the downstream pathophysiology linking the 
gene defect to the development of disease remains obscure. In parallel, extensive in-vitro and in-vivo studies widened our understanding of the molecular basis of heart development. It is thought that perturbations during embryonic heart development are at the origin of CHD. These studies resulted in large sets of candidate genes and molecular pathways involved in heart development. It is hypothesized that mutations in these genes cause CHD. This was confirmed by sequencing of genes encoding cardiac-enriched transcription factors such as GATA4, NKX2-5, and TBX5 in non-syndromic cases of CHD, and finding mutations that segregate with the disease. This prompted excitement in the field; however, screening of large cohorts of isolated CHD cases brought some disappointment as these genes explained only a minority of the cases.

The understanding of how defects in these genes cause CHD turned out to be more complicated that initially expected. It became evident that not all CHD manifests true Mendelian inheritance. It is possible that combinations of mutations in different genes result in a particular phenotype, or combination of a gene mutation with a particular environmental exposure results in a CHD phenotype. Mutations might have low penetrance and only serve to increase the risk of CHD. Other mutations might yield totally defective proteins, yet be compensated for by other proteins in interlinked pathways. Copy Number Variations (CNVs), altered transcription, somatic mutations, and microRNA (miRNA) are also additional mechanisms through which the molecular basis of CHD can be explained. Current research explores all of these mechanisms with a wide array of technologies that are better than ever, and hence the future decade promises a near complete understanding of heart development and the genetic basis of Congenital Heart Disease.

This chapter covers the genetics of syndromic and non-syndromic congenital heart disease. It discusses all genes that have been associated with congenital heart disease in humans with depiction of the spectrum of mutations and the genotype-phenotype correlations for each. The chapter also covers the roles of CNVs, epigenetics, somatic mutations, and miRNA in CHD. Current technologies and strategies used to understand the genetics of congenital heart disease are also discussed. The chapter ends with an explanation of how these technologies can unravel the genetics of CHD and allow the application of research findings for the benefit of patients.

\section{Classifications, anatomy, and clinical significance}

Congenital heart disease encompasses a broad category of anatomic malformations, which can range from a small septal defect or leaky valve to a severe malformation requiring extensive surgical repair or leading to death such as a single ventricle. Several classification systems exist for describing congenital heart disease. The most common classification used to describe CHD is purely clinical whereby CHD is cyanotic if the malformation results in deoxygenated blood bypassing the lung and causes cyanosis (blue patient), or non-cyanotic if the malformation does not result in cyanosis. The most common cyanotic heart defects are Tetralogy of Fallot (TOF), Hypoplastic Left Heart Syndrome (HLHS), Transposition of the Great Arteries (TGA), Truncus Arteriosus (TA), and Total Anomalous Pulmonary Venous 
Connection (TAPVC). Congenital heart defects can also be simple or complex. A complex malformation includes several simple malformations occurring together. The most typical example is Tetralogy of Fallot, which -as its name implies- includes four malformations: Pulmonary Stenosis (PS), an overriding aorta, Ventricular Septal Defect (VSD), and right ventricular hypertrophy. Because of the wide diversity in the anatomy of the cardiac malformations, several detailed morphological classifications were also developed. The most widely recognized one is the International Pediatric and Congenital Cardiac Code (IPCCC), which was developed by the International Society for Nomenclature of Paediatric and Congenital Heart Disease (ISNPCHD). Table 1 shows the categories of CHD classifications of the IPCCC with the most common diagnoses within each category. The detailed version could be downloaded from the IPCCC website (www.ipccc.net). Other classification systems are radiologic based on echocardiography or magnetic resonance imaging, hemodynamic based on shunts and circulations in the heart, or embryological based on the presumed origin during heart development. CHD can occur as part of a syndrome and as such is labeled as syndromic or nonsyndromic, both of which are discussed in this chapter. In syndromic and non-syndromic cases, CHD can be isolated, that is occurring in a single patient, or familial afflicting many members within the same family. The recurrence rate of CHD after an isolated case is 2.7\%. (Gill and others 2003)

This anatomical heterogeneity of $\mathrm{CHD}$ has been one major reason why we know little about its genetics. Beyond the anatomical classification described in the IPCCC, different combinations of malformations and variations to described malformations can occur. Pediatric cardiologists often end up using different terminologies to describe similar defects because of their complexity. Extremely rare complex malformations are also sometimes described and run in families while their cause remains unknown.(Herrera and others 2008; Jaeggi and others 2008) Genotype-phenotype correlations are hard to establish due to this heterogeneity. In the majority of familial cases of $\mathrm{CHD}$, there are different types of structural malformations within the same family. The same single gene mutation has been shown to cause a variety of cardiac defects, even within the same family.(Goldmuntz 2001) Whenever mouse knockout models were developed to recapitulate a human CHD phenotype, the mouse phenotype was not always similar to that seen in humans.(Bruneau 2008) All these issues raised the hypothesis of a multifactorial and perhaps polygenetic origin of CHD. The genetic background of the individual, in-utero environment, epigenetic changes, and embryological hemodynamics and physiology are all possible causes of this phenotypic heterogeneity.

Being a leading cause of deaths in the first year of life, CHD has prompted a large wave of development in surgical and interventional procedures to treat CHD. As such, CHD is mostly corrected with surgical and interventional procedures when the malformation causes symptoms or can cause heart failure such as a large septal defect or a cyanotic heart disease. Small malformations such as tiny septal defects that are expected to correct on their own or to not cause any complication are simply observed. With the recent advances in treatment, the mortality from CHD has decreased tremendously and most CHD patients survive a normal life throughout adulthood.(van der Bom and others 2011) This prompted a whole 
new subspecialty in adult cardiology to take care of adult patients with CHD.(Moodie 1994) As these adults with CHD are planning to have children of their own, the recurrence risk became a problem, and this was yet another force to identify the genetic causes behind the disease, given that genetic counseling and pre-implantation genetic diagnosis (PGD) can be useful tools for these parents.

\begin{tabular}{|c|c|}
\hline Classification Category & Most Common Diagnoses \\
\hline $\begin{array}{c}\text { Abnormalities of position } \\
\text { and connection of the } \\
\text { heart }\end{array}$ & $\begin{array}{c}\text { Dextrocardia } \\
\text { Atrial Situs Inversus } \\
\text { Double Inlet Left Ventricle (DILV); Double Inlet Right Ventricle (DIRV) } \\
\text { Transposition of the Great Arteries (TGA) } \\
\text { Double Outlet Left Ventricle (DORV); Double Outlet Right Ventricle } \\
\text { (DORV) } \\
\text { Common Arterial Trunk (CAT), aka Truncus Arteriosus (TA) }\end{array}$ \\
\hline $\begin{array}{c}\text { Tetralogy of Fallot and } \\
\text { variants }\end{array}$ & $\begin{array}{c}\text { Tetralogy of Fallot (TOF) } \\
\text { Pulmonary Atresia (PA) and Venticular Septal Defect (VSD) }\end{array}$ \\
\hline $\begin{array}{l}\text { Abnormalities of great } \\
\text { veins }\end{array}$ & $\begin{array}{c}\text { Supervior Vena Cava (SVC) Abnormality } \\
\text { Inferior Vena Cava (SVC) Abnormality } \\
\text { Coronary Sinus Abnormality } \\
\text { Total Anomalous Pulmonary Venous Connection (TAPVC) } \\
\text { Partially Anomalous Pulmonary Venous Connection (PAPVC) }\end{array}$ \\
\hline $\begin{array}{l}\text { Abnormalities of atriums } \\
\text { and atrial septum }\end{array}$ & $\begin{array}{c}\text { Atrial Septal Defect (ASD) } \\
\text { Patent Foramen Ovale (PFO) }\end{array}$ \\
\hline $\begin{array}{c}\text { Abnormalities of AV } \\
\text { valves and AV septal } \\
\text { defect }\end{array}$ & $\begin{array}{c}\text { Tricuspid Regurgitation (TR) } \\
\text { Tricuspid Stenosis (TS) } \\
\text { Ebstein's Anomaly } \\
\text { Mitral Regurgitation (MR) } \\
\text { Mitral Stenosis (MS) } \\
\text { Mitral Valve Proplapse (MVP) } \\
\text { Atrioventricular Septal Defect (AVSD) } \\
\end{array}$ \\
\hline $\begin{array}{c}\text { Abnormalities of } \\
\text { ventricles and ventricular } \\
\text { septum }\end{array}$ & $\begin{array}{c}\text { Single Ventricle } \\
\text { Ventricular imbalance: dominant LV +hypoplastic RV, or dominant } \\
\text { RV+hypoplastic RV } \\
\text { Aneurysm (RV, LV, or septal) } \\
\text { Hypoplastic Left Heart Syndrome (HLHS) } \\
\text { Double Chambered Right Ventricle (DCRV) } \\
\text { Ventricular Septal Defect (VSD) }\end{array}$ \\
\hline $\begin{array}{l}\text { Abnormalities of VA } \\
\text { valves and great arteries }\end{array}$ & $\begin{array}{c}\text { Aortopulmonary Window (AP Window) } \\
\text { Pulmonary Stenosis (PS), valvar or subalvar } \\
\text { Pulmonary Artery Stenosis (PAS) } \\
\text { Aortic Stenosis (AS), valvar or suvalvar } \\
\text { Aortic Insufficiency (AI) } \\
\text { Bicuspid Aortic Valve (BAV) } \\
\text { Supravalvar Aortic Stenosis (SVS) } \\
\text { Coarctation of the Aorta (COA) } \\
\text { Interrupted Aortic Arach (IAA) } \\
\end{array}$ \\
\hline $\begin{array}{l}\text { Abnormalities of } \\
\text { coronary arteries, arterial } \\
\text { duct and pericardium; } \\
\text { AV fistulae }\end{array}$ & $\begin{array}{c}\text { Anomalous Origin of Coronary Artery from Pulmonary Artery } \\
\text { (ALCAPA) } \\
\text { Patent Ductus Arteriosus (PDA) }\end{array}$ \\
\hline
\end{tabular}

Table 1. IPCCC Classification of Congenital Heart Disease and Most Common Diagnoses 


\section{Developmental genetics of congenital heart disease}

Heart development is crucial to understand because its molecular basis is evolutionary conserved as depicted by studies in several model organisms. Heart development is a complex process regulated by combinatorial interactions of transcription factors and their regulators, ligands and receptors, signaling pathways, and contractile protein genes among others. The differential expression of each of these genes at unique stages of development and in different areas of the heart is responsible for the normal development of the heart. Any disruption in these genes will result in congenital malformations of the heart. This molecular program for heart development has been a heavy field of research, yet our knowledge is far from being complete.

The heart is the first organ to develop in the embryo at the second week of gestation when pre-cardiac lateral plate mesoderm cells migrate towards the midline of the embryo and form two crescent-shaped primordia, which fuse to form a beating heart tube at week 3 . Within only few days the heart tube folds on itself in a process known as looping. This is the first event in the organogenesis of the embryo that manifests left-right asymmetry and is believed to be at the origin of the laterality program of the embryo. Subsequently, the four chambers of the heart are formed. This requires the differentiation of myocytes into two different subtypes, atrial and ventricular. Finally, valves and septa form through divisions within the heart to form the mature four-chambered heart. Valvulogenesis and septogenesis both require interaction between endocardial and myocardial cells, and valvoseptal malformations are the most common CHDs. In addition, development of the conduction system occurs into pacemakers and purkinjie cells, as well as vascularization from neural crest cells, and coronary arteries from epicardial precursor cells. As such, heart development requires a complex interplay of cell-commitment, migration, proliferation, differentiation, and apoptosis. Any perturbation in this program can result in congenital heart disease.

Transcription factors regulate this tight program of gene expression, which is chamber-, and stage-specific. Protein interactions and formation of complexes that regulate downstream targets cardiac targets with convergent and divergent pathways have made the understanding of the molecular basis of CHD complicated. In-vitro and invivo studies have been crucial in widening our understanding of the molecular program for heart development. Major transcription factor families involved in heart development include the GATA, T-box, homeobox, and basic Helix-Loop-Helix (bHLH) among others. Screening of human CHD patients for gene mutations within these transcription factor families as well as other cardiac-enriched genes implicated in heart development has not been as rewarding. Mutations in TBX5, GATA4, NKX2-5 have been implicated in many CHD families and genetic tests became clinically available. Several other genes have been clearly established to cause syndromic cases of CHD such as $J A G 1$ and ELN. Deletions of chromosomal regions have also been established to cause several CHD syndromes, the most famous of which is DiGeorge Syndrome, which is caused by the 22q11.2 deletion. Despite all this progress, the majority of gene mutations 
discovered in a family with CHD have not been confirmed in other families, or in only a few. Also screening of large cohorts of isolated CHD cases for mutations in a large set of cardiac-enriched candidate genes consistently results in a low yield of genetic causality.

This gap has prompted novel directions in understanding the genetics of CHD. One of the hypotheses is the multifactorial and polygenetic nature of $\mathrm{CHD}$, with gene mutations acting on a certain genetic background or acting within a particular susceptible environment within a developmental window. There have been efforts towards a new systems biology approach to understanding CHD. In addition to germline DNA sequencing which comprises the majority of the literature, somatic DNA sequencing, RNA sequencing, study of microRNAs (miRNAs), and Copy Number Variations (CNVs) analysis are becoming more popular tools to study CHD. Also with the advent of next-generation sequencing and the decreased cost of both sequencing and array comparative genomic hybridization (arrayCGH), more data are becoming available, and the molecular biology approach of the past few decades is shifting into a bioinformatics approach to help decipher the genetics of this complex disease. The subsequent sections of the chapter will dwell into the genetics of CHD from the oldest and most known to the most recent and least known. The below section discusses syndromic CHD, which comprises entities where the genetic causes is the most well established. Then the genes implicated in non-syndromic CHD in humans will be discussed with the degree of evidence for each. The most recent but least developed technologies to understand CHD mentioned above will be discussed at the end of the chapter.

\section{Syndromic congenital heart disease}

Cardiac malformations are among the most prevalent malformations in congenital syndromes. A large list of syndromes with congenital heart disease as a common manifestation has known genetic defects. CHD syndromes can be either due chromosome dosage disorders, large chromosomal deletions, small micro-deletions, or single gene defects. Table 2 shows a list of CHD syndromes within each of these categories with the corresponding genetic defect. This section will discuss the most common syndromes that include congenital heart disease as a primary manifestation. Within each syndrome, the phenotypic diversity as well as the spectrum of mutations and chromosomal defects that have been reported will be discussed.

\subsection{Down Syndrome (trisomy 21)}

Down Syndrome is the most common disorder of chromosome dosage with an incidence of 1 in 700 to 1 in 800 live births. The incidence is known to increase tremendously with increased maternal age, particularly above the age of 35 . The main clinical manifestations of Down Syndrome are characteristic dysmorphic facies, mental retardation, premature ageing, congenital heart disease, hearing loss, and increased risk of hematologic malignancies.(Pueschel 1990) 


\begin{tabular}{|c|c|}
\hline Syndrome with CHD & Genetic Cause for CHD \\
\hline Disorders of Chromosome Dosage \\
\hline Trisomy 21 (Down Syndrome) & Unknown \\
\hline Turner & Unknown \\
\hline \multicolumn{2}{|c|}{ Chromosomal Microdeletions } \\
\hline Di Georges Syndrome & 22q11.2 deletion resulting in absent \\
SBIle Gene Defects gene
\end{tabular}

Table 2. Syndromes Manifesting Congenital Heart Disease and their Genetic Cause

Congenital Heart Disease occurs in 40 to $50 \%$ of Down Syndrome patients. The most common abnormality is Atrioventricular Septal Defect (AVSD).(Marino 1993) Other malformations include VSD and TOF among others. Some CHD phenotypes are not seen in Down Syndrome patients such as Transposition of the Great Arteries (TGA) and Situs Inversus.(Marino 1993) Adult patients with Down Syndrome are also predisposed to Mitral Valve Prolapse (MVP) and fenestrations in the cusps of the aortic and pulmonary valves. (Hamada and others 1998)

Given the complexity of the phenotype in Down Syndrome, there has been tremendous effort to build a phenotype map and identify the genetic cause behind each phenotype.(Delabar and others 1993; Korenberg and others 1994) Although successful for other features of Down Syndrome, the cause of the cardiac malformations in Down Syndrome are still unclear. Knowing that CRELD1 gene mutations have been associated with AVSD, one screening of 39 Down Syndrome patients identified two missense CRELD1 
mutations and suggested that CRELD1 mutations might cause AVSD in Down Syndrome.(Maslen and others 2006) However other complex hypotheses have been suggested such as epigenetic mechanisms. Despite considerable process for molecular genetic analysis of Down Syndrome has been achieved using mouse models, to date no clear cause for CHD is known.

\subsection{Turner Syndrome}

Turner syndrome is a condition in females where all or part of one sex chromosome is absent. It is estimated to occur in 1 of 2500 females.(Bondy 2009) It manifests most commonly with characteristic physical features such as short stature, webbed necks, broad chest, low hairline, and low set ears, gonadal dysfunction, and cognitive deficits.(Bondy 2009) Clinical features are highly variable and can sometimes be very mild. Congenital heart disease is found in $20 \%$ to $50 \%$ of Turner Syndrome patients. The most common malformation is a Coarctation of the Aorta (COA) of the postductal type, which comprises $50 \%$ to $70 \%$ of CHD in Turner Syndrome.(Doswell and others 2006) Other cardiac malformations seen in Turner Syndrome include Bicuspid Aortic Valve (BAV), Partial Anomalous Pulmonary Venous Connection (PAPVC), and Hypoplastic Left Heart (HLH). In addition, a higher frequency of cardiac conduction abnormalities, hypertension, and aortic dilation has been reported in Turner Syndrome patients.(Doswell and others 2006; Lopez and others 2008) The molecular mechanisms leading to the cardiac malformations in Turner Syndrome are not clear.

\subsection{Di George Syndrome}

Di George Syndrome (DGS) is also known as Velocardiofacial Syndrome (VCFS) or Chromosome 22q11.2 Deletion Syndrome. It is caused by a 1.5 to $3.0-\mathrm{Mb}$ hemizygous deletion on chromosome 22 q11, which can be inherited in an autosomal dominant fashion, but most commonly arises de novo.(Emanuel 2008) The clinical manifestations are highly variable owing to incomplete penetrance. When the disease is fully penetrant, clinical manifestations include cardiac outflow tract defects, parathyroid gland hypoplasia resulting in hypocalcaemia, thymus gland aplasia resulting in immunodeficiency, and neurologic and facial abnormalities.(Emanuel 2008) Cardiac outflow tact defects in DGS include TOF, type B Interrupted Aortic Arch (IAA), Truncus Arteriosus, Right Aortic Arch, and aberrant right subclavian artery.(Momma 2010) (Yagi and others 2003) The molecular mechanisms leading to the phenotype in DGS are more known than for Down and Turner Syndromes. The microdeletion results in haploinsufficiency of the TBX1 gene, which is responsible for neural crest migration into the derivatives of the pharyngeal arches and pouches in the developing embryo.(Emanuel 2008) Target genes downstream of TBX1 are not yet elucidated, however they are most likely to explain the different phenotypes in DGS.

\subsection{Williams-Beuren Syndrome}

Williams-Beuren Syndrome (WBS) results from a hemizygous deletion of 1.5 to $1.8 \mathrm{Mb}$ on chromosome 7q11.23, an area that encompasses 28 genes. Its prevalence is estimated to be 1 
in 7500.(Stromme and others 2002) Clinically, patients have Supravalvular Aortic Stenosis (SVAS), mental retardation, characteristic facial features, distinctive dental anomalies, infantile hypercalcemia, and peripheral pulmonary artery stenosis.(Beuren and others 1962; Grimm and Wesselhoeft 1980; Williams and others 1961) The cardiac phenotype of vascular stenosis is caused by haploinsufficiency of the Elastin (ELN) gene and is found in at least $70 \%$ of the patients.(Pober 2010) Mutations of the ELN gene also result in familial cases of SVAS without the syndromic features of Williams-Beuren.(Curran and others 1993; Metcalfe and others 2000) Although SVAS is the most common lesion in WBS patients, vascular stenoses can occur in any medium or large artery due to the thick media layer. Lesions have been described in aortic arch, descending aorta, pulmonary, coronary, renal artery, mesenteric arteries, and intracranial arteries.(Pober 2010) Half of Williams-Beuren patients also suffer form hypertension, and cardiovascular disease is the most common cause of death in these patients.(Pober 2010; Pober and others 2008)

\subsection{Holt-Oram Syndrome}

Holt-Oram Syndrome (HOS) is also known as Heart-Hand Syndrome, and it manifests as congenital heart disease and upper limb dysplasia. The heart manifestations are mostly septal malformations and include secundum ASD, VSD, patent ductus arteriosus, and conduction system abnormalities. The upper limb malformations are widely variable but are typically bilateral and asymmetric in severity. They can range from a small abnormality such as a distally-placed thumb to phocomelia or hypoplasia of the shoulders and clavicles. Sometimes the upper limb dysplasia can go unnoticed and will be seen only after radiological imaging. Congenital heart malformations occur in $85 \%$ of HOS patients.(Basson and others 1994; Boehme and Shotar 1989)

Genetically, HOS is an autosomal dominant disease caused by mutations in the TBX5 gene, a member of the T-box family of transcription factors. (Basson and others 1997; Li and others 1997b) Haploinsufficiency of TBX5 was shown to be at the origin of the HOS. TBX5 interacts with other cardiac-specific transcription factors GATA4 and NKX2-5 to regulate the expression of downstream genes such as ID2, which are essential in septation of the cardiac chambers as well as development of the conduction system. The functional mechanisms through which the three transcription factors TBX5, GATA-4, and Nkx2-5 interact to mediate processes in heart development have been heavily studied, and there is a very complex network of interactions among these and other transcription factors and downstream genes that exists but that is still partially understood (Figure 1).

Genotype-phenotype correlations were also performed in HOS, and it has been shown that TBX5 mutations that create null alleles result in more severe abnormalities in both upper limbs and the heart as compared to missense mutations.(Basson and others 1999) Some mutations caused very severe cardiac malformations but only subtle upper limb deformities. From a clinical perspective, it is important to look for subtle upper limb malformations in patients with septal deformities, because a diagnosis of HOS can increase the recurrence risk in a sibling from $3 \%$ to $50 \%$ given that this is an autosomal dominant disease. Clinical genetic testing for TBX5 has also become available in some laboratories across the world. 


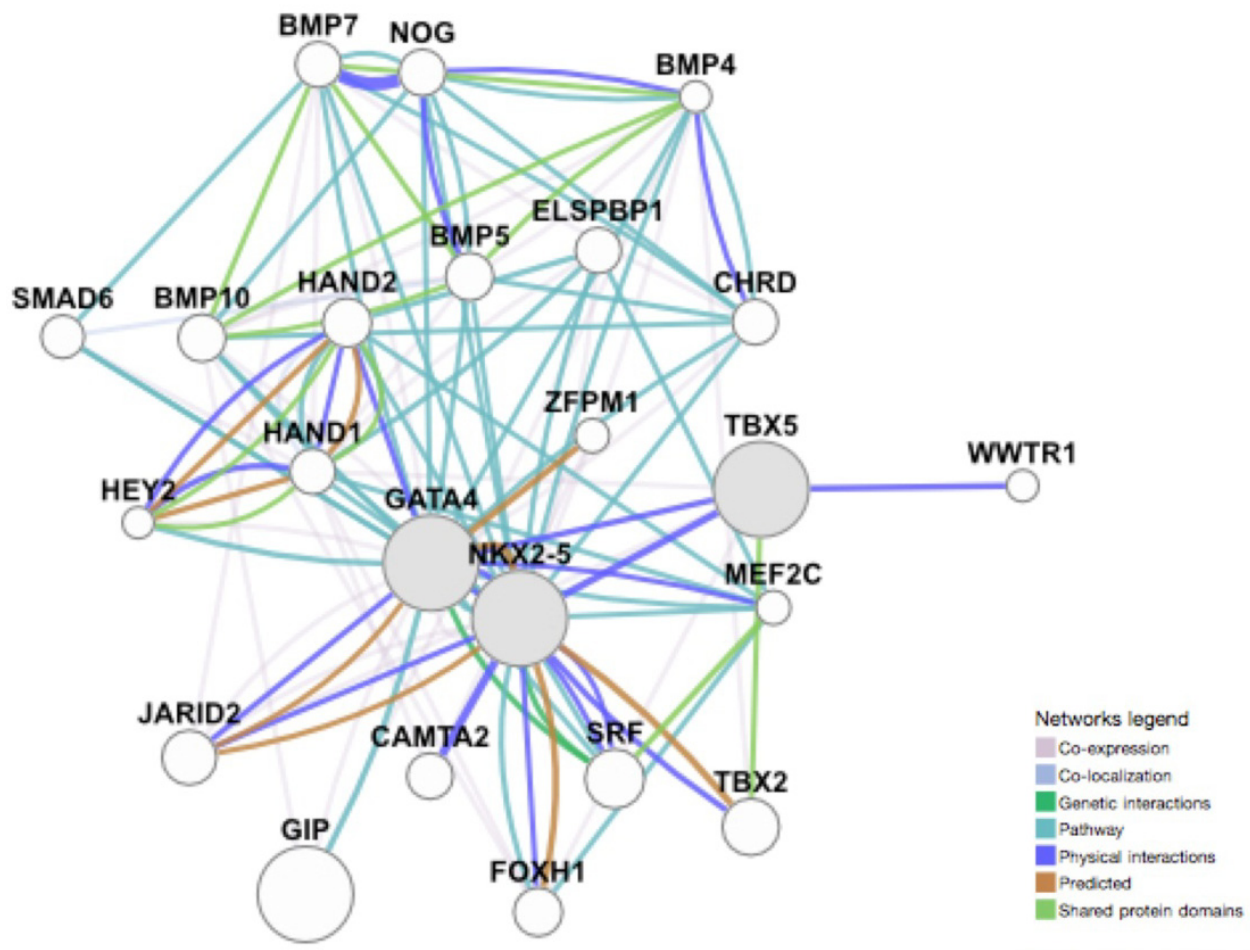

Figure 1. Complex Genetic Interactions of TBX5, GATA4, and Nkx2-5 (Network created using www.genemani.org )

\subsection{Alagille Syndrome}

Alagille Syndrome is inherited in an autosomal dominant fashion and is defined in the presence of intrahepatic bile duct paucity that usually manifests as cholestasis, congenital heart disease, distinctive facies, skeletal, ocular, renal, and neurological abnormalities. (Kamath and others 2011; Li and others 1997a) CHD is found in more than 90\% of patients with Alagille Syndrome and the most common lesion is Pulmonary Atery Stenosis (PAS) or hypoplasia. Other common lesions include TOF, pulmonary valve stenosis (PS), and ASD.(McElhinney and others 2002) The prevalence of the disease is estimated at around one in 700,000 neonates when presence of jaundice is used to ascertain cases (Danks and others 1977), but in fact the disease has a tremendous variability in the phenotype and variable penetrance in families so that the actual prevalence is expected to be much higher.

Alagille Syndrome is caused by mutations in the JAG1 gene.(Li and others 1997a; Oda and others 1997) The gene encodes a ligand to the Notch1 receptor. Jagged-Notch cell-cell interactions are crucial in determining cell fates during early developmental processes. The mutations spectrum of JAG1 in Alagille Syndrome encompasses frameshift mutations, nonsense mutations, splice site mutations, or deletion of the whole gene.(Yuan and others 
1998) Mutations have also been identified in patients with a predominantly cardiac phenotype.(Li and others 1997a) Some families do have variable penetrance of the mutation as well as variant expressivity of the disease within the same family, such as facial dysmorphism only, or subtle liver disease only within members of the family carrying the same mutation.(El-Rassy and others 2008) JAG-1 mutations are present in $94 \%$ of patients that are clinically diagnosed with Alagille Syndrome. A small number of cases are also explained by mutations in the Notch1 gene, the JAG-1 receptor.(McDaniell and others 2006).

Clinical testing for $J A G-1$ mutations is available. If patients are clinically diagnosed, a $J A G-1$ mutation could confirm the diagnosis, and indicate the need for multisystem assessment to look for other subclinical abnormalities and possibly prevent them. It would also allow for similar assessment of family members. Due to the high variability of the disease, patients with suspicious right-sided heart lesions such as PAS, TOF, and PS who do not necessarily fulfill the criteria for Alagille Syndrome could also be tested for JAG-1 mutations.

\subsection{Noonan Syndrome}

Noonan Syndrome (NS) is a dysmorphic cardiofacial syndrome inherited mostly in an autosomal dominant fashion, with some cases occurring sporadically. Its incidence ranges between 1 in 1000 to 1 in 2500 live births.(Tartaglia and others 2010) The characteristic physical features are downward eyeslanting of the eyes, hypertelorism, low-set ears, short stature, short and webbed neck, and epicanthic folds.(Tartaglia and others 2010) Congenital Heart Disease is found in 80 to $90 \%$ of patients with Noonan Syndrome and valvar pulmonary stenosis (PS) and Hypertrophic Cardiomyopathy (HCM) are the two most common cardiac manifestations. A large set of cardiac malformations can also occur including secundum ASD, AVSD, TOF, COA, VSD, PDA, and mitral valve disease.(Marino and others 1999; Noonan 1994) Patients might also have deafness, cryptorchidism, motor delay, and bleeding diathesis.(Tartaglia and others 2010)

NS is a genetically heterogeneous syndrome with at least 8 genes that have been associated with the disease so far: PTPN11, SOS1, RAF1, KRAS, BRAF, MEK1, MEK2, and HRAS.(Tidyman and Rauen 2009) Mutations in PTPN11 are most common and explain 50\% of the Noonan Syndrome cases, the other 7 genes explain roughly $25 \%$ of the cases, and in about $25 \%$ of the cases no mutation is found.(Tartaglia and others 2010) All the genes implicated in NS encode proteins that are part of the Ras/Raf/MEK/ERK signaling pathway, an important regulator of cell proliferation, differentiation, and survival. PTPN11 encodes SHP-2, a protein tyrosine phosphatase that plays an important role in the signal transduction to medial the biological processes described above.

Disease penetrance is almost complete with PTPN11 mutations, but there is a wide variability in the phenotype. Clinical testing for some of the genes involved in NS such as PTPN11, SOS1, and KRAS is available. Clinical diagnosis might be helpful might be helpful in borderline cases given the variability in the phenotype. 


\section{Nonsyndromic congenital heart disease}

Isolated congenital heart disease is the most prevalent form of $\mathrm{CHD}$. Evidence for the genetic basis of isolated CHD comes from familial clustering of cases as well as higher recurrence rate of $\mathrm{CHD}$. Mutations in many genes have been associated with several CHD phenotypes, yet the evidence is variable for each gene. Gene mutations can best be classified as highly penetrant mutations in disease-causing genes, low-penetrance mutations in susceptibility genes, and common variants in CHD risk-genes. Transcription factor genes are the most common group of genes implicated in CHD. Other genes are part of signaling transduction pathways and structural components of the heart. Evidence for each gene comes from family studies and segregation analyses using direct sequencing. As mentioned earlier, one of the biggest challenges in the genetics of nonsyndromic CHD is that sequencing for all genes implicated in CHD explains the genetic cause of only a small percentage of patients. Most gene mutations have been described in one or few cases, while only a small number of genes have been duplicated in many cohorts and families.

Table 3 lists all genes in which mutations have been found in different nonsyndromic CHD phenotypes. Most of these are based on only few cases and hence remain to be ascertained; however some have been duplicated in several families such as the phenotypes associated with NKX2-5 or GATA4 mutations. The table lists all the genes in which mutations have ever been described for each phenotype. The corresponding PubMed IDs are provided for the published studies where these gene mutations are reported so that readers can make their own assessment regarding the strength of the association.

\begin{tabular}{|l|l|l|}
\hline Phenotype & Implicated Genes & PubMed ID \\
\hline Dextrocardia & ACVR2B, NODAL, ZIC3 & $\begin{array}{l}9916846,19064609, \\
14682828\end{array}$ \\
\hline Tricuspid Atresia & MYH6 & 15643620,15389319 \\
\hline Mitral Atresia & FLNA & 20730588 \\
\hline Transposition of the Great & NODAL, FOXH1, CFC1, & 9916847,14638541, \\
Arteries (TGA) & THRAP2, GDF1, ACVR2B, & 17924340,11799476, \\
& ZIC3, NKX2-5, MYH6 & 18538293,19553149, \\
& & 19933292,19064609, \\
& & 17295247,19933292, \\
& & 14681828,18538293, \\
& & 1460745420656787 \\
\hline Double Outlet Right Ventricle & NODAL, FOG2, GDF1, & 9916847,17924340, \\
(DORV) & CFC1, ACVR2B, NKX2-5 & 11799476,19553149, \\
& & 14681828,20807224, \\
& & 14607454 \\
\hline Common Arterial Trunk & GATA6, NKX2-5, Nkx2-6 & 19666519,14607454, \\
(CAT) & & 15649947 \\
\hline
\end{tabular}




\begin{tabular}{|c|c|c|}
\hline Tetralogy of Fallot (TOF) & $\begin{array}{l}\text { Nkx2-5, NODAL, CFC1, } \\
\text { FOXH1, GATA4, FOG2, } \\
\text { GDF1, HAND2, ALDH1A2, } \\
\text { GATA6, TDGF1, JAG1 }\end{array}$ & $\begin{array}{l}20437614,19886994, \\
17924340,16470721, \\
18538293,20581743, \\
19553149,18538293, \\
18538293,20819618, \\
14517948,14607454\end{array}$ \\
\hline $\begin{array}{l}\text { Total Anomalous Pulmonary } \\
\text { Venous Connection (TAPVC) }\end{array}$ & $\begin{array}{l}\text { NODAL, PDGFRA, } \\
\text { ANKRD1, ZIC3 }\end{array}$ & $\begin{array}{l}20071345,18273862 \\
19064609,14681828 \\
\end{array}$ \\
\hline $\begin{array}{l}\text { Partial Anomalous Pulmonary } \\
\text { Venous Connection (PAPVC) }\end{array}$ & GATA4 & 18076106 \\
\hline ASD & $\begin{array}{l}\text { NKX2-5, GATA4, GATA6, } \\
\text { TBX20, CFC1, CITED2 }\end{array}$ & $\begin{array}{l}18159245,1480002, \\
15689439,12845333, \\
17072672,19853937, \\
19666519,16287139, \\
17668378,9651244, \\
15810002, \\
15689439,14607454\end{array}$ \\
\hline Ebstein 's Anomaly & MYH7 & 21127202 \\
\hline $\begin{array}{l}\text { Atrioventricular Septal Defect } \\
\text { (AVSD) }\end{array}$ & $\begin{array}{l}\text { NODAL, GATA4, ACVR1, } \\
\text { CRELD1, CFC1, LEFTY2 }\end{array}$ & $\begin{array}{l}12845333,20670841, \\
19064609,19506109, \\
12632326,15857420, \\
18538293,10053005\end{array}$ \\
\hline $\begin{array}{l}\text { Hypoplastic Left Heart } \\
\text { Syndrome (HLH) }\end{array}$ & $\begin{array}{l}\text { NOTCH1, NKX2-5, GJA1, } \\
\text { ZIC3 }\end{array}$ & $\begin{array}{l}\text { 18593716, 14607454, } \\
\text { 20456451, 11470490, } \\
14681828\end{array}$ \\
\hline VSD & $\begin{array}{l}\text { NKX2-5, GATA4, CFC1, } \\
\text { IRX4, ZIC3, TDGF1, } \\
\text { CITED2, TBX20 }\end{array}$ & $\begin{array}{l}21544582,12845333, \\
17253934,18055909, \\
19853937,14681828, \\
19853938,16287139, \\
17668378,12074273, \\
9651244,10587520\end{array}$ \\
\hline $\begin{array}{l}\text { Pulmonary Valve Stenosis } \\
\text { (PS) }\end{array}$ & $\begin{array}{l}\text { ELN, GATA4, ACVR2B, } \\
\text { ZIC3, GATA6 }\end{array}$ & $\begin{array}{l}21080980,9916847, \\
12845333,19666519, \\
14681828\end{array}$ \\
\hline $\begin{array}{l}\text { Pulmonary Artery Stenosis } \\
\text { (PAS) }\end{array}$ & $E L N, J A G 1$ & $\begin{array}{l}16944981,11175284, \\
10942104,20437614 \\
\end{array}$ \\
\hline Aortic Valve Stenosis (AS) & NOTCH1, ELN, MYH6 & $\begin{array}{l}21080980,16025100, \\
20656787\end{array}$ \\
\hline Bicuspid Aortic Valve (BAV) & NOTCH1 & 16729972,160251100 \\
\hline $\begin{array}{l}\text { Supravalvar Aortic Stenosis } \\
\text { (SVAS) }\end{array}$ & $E L N$ & $\begin{array}{l}\text { 9215670, 16944981, } \\
11175284\end{array}$ \\
\hline Coarcation of the Aorta & VEGF, NOTCH1, NKX2-5, & 20420808, 10053005, \\
\hline
\end{tabular}




\begin{tabular}{|l|l|l|}
\hline (COA) & LEFTY2 & 18593716,14607454 \\
\hline Interrupted Aortic Arch (IAA) & CFC1, LEFTY2, NKX2-5 & $\begin{array}{l}18538293,10053005, \\
14607454\end{array}$ \\
& & $\begin{array}{l}16444274,17956658, \\
18752453\end{array}$ \\
\hline Patent Ductus Arteriosus & MYH11, TFAP2B & \\
(PDA) & & \\
\hline
\end{tabular}

Table 3. Implicated Genes in Different Nonsyndromic CHD Phenotypes

In the remaining part this section, the most common genes implicated in nonsyndromic $\mathrm{CHD}$ are discussed in details. For each gene, the mutational spectrum, function, associated CHD phenotypes, and mechanism of disease (if known) are provided. The three large groups of cardiac specific transcription factors, the GATA (GATA4, GATA5, and GATA6), Homebox (Nkx2-5 and Nkx2-6), and T-box (TBX1, TBX5, and TBX20) are first discussed in detail each in a separate subsection. These three categories of genes comprise the majority of the known genetic causes of CHD. Genes from all three categories interact to regulate downstream gene expression in the developing heart. Other transcription factor genes are discussed in a separate section. Different signaling pathway genes such as the NODAL signaling genes and the Notch signaling pathway are discussed separately. Contractile protein genes, in addition to their well-established role in cadiomyopathy, have been associated with CHD and are mentioned under one section. All remaining genes with minimal evidence for causing CHD comprise are clustered under the final subtitle of this section of the chapter.

\subsection{GATA transcription factors (GATA4, GATA5, GATA6)}

GATA-binding proteins are a family of transcription factors that regulate gene expression and are involved in cell differentiation, survival, and proliferation in many tissues. GATA proteins are evolutionary conserved proteins containing two zinc-finger motifs. They recognize and bind to a "GATA" consensus sequence, which is an important cis-element of the promoters of many genes.

GATA4, GATA5, and GATA6 are involved in the developing heart, and knockout studies in mice have shown that all three are essential for normal cardiac development. Silencing of GATA genes can result in cardiac malformations ranging from valvoseptal defects to acardia. However, mutations in humans with CHD have been described only in GATA4 and GATA6 but not GATA5.

GATA genes are also among the earliest transcription factors to be expressed in the developing heart. They are expressed in different but overlapping time and tissue patterns in the embryonic heart and manifest complex combinatorial interactions. These characteristics seem to be essential for proper embryonic and postnatal cardiac development.

GATA4 mutations are a well-established cause of CHD in humans. They are inherited in an autosomal dominant fashion in familial cases and are also seen in isolated cases. Haploinsufficiency of the GATA4 gene causes CHD, which is highly penetrant as observed 
in familial studies. The most common phenotypes were causative GATA4 mutations are found are ASD, VSD, TOF, and AVSD.(Garg and others 2003; Nemer and others 2006) Findings of GATA4 mutations have been duplicated in many familial studies.(Chen and others 2010; Garg and others 2003) Multiple phenotypes are often seen within the same family segregating the same mutation. In isolated studies of CHD cohorts with phenotypes within the spectrum of phenotypes obtained from GATA4 knockout mice, the frequency of GATA4 mutations ranges between $0.8 \%$ and 3.7\%.(Peng and others 2010; Rajagopal and others 2007; Tomita-Mitchell and others 2007; Zhang and others 2006) The spectrum of mutations in GATA4 includes missense mutations as well as mutations that truncate the protein such as nonsense, frameshift, or splice site variants. Disease-causing missense mutations often disturb the cooperative binding of GATA4 to other transcription factors such as Nkx2-5 and TBX5 (Figure 1), a process which is essential for modulating downstream gene expression during cardiac development.

Animal studies have shown that while $\mathrm{Gata4}^{+/}$and $\mathrm{Gata6}^{+/-}$mice survive normally, compound heterozygous Gata4 $^{+-}$Gata6 $^{+-}$mice die at embryonic day 13.5 due to severe cardiac malformations.(Xin and others 2006) Also when both genes are knocked out completely, mice fail to develop any heart.(Zhao and others 2008) These studies have shown that both Gata4 and Gata6 are essential for cardiac development and that they interact to regulate downstream targets during heart development. Inactivating Gata6 in specific vascular cells using transgenic mice has also shown that Gata6 is involved in the migration of neural crest cells and differentiation of terminal smooth muscle cells, late processes in cardiac development.(Lepore and others 2006) Sequencing of patients with CHD corroborated animal findings by identifying heterozygous GATA6 mutations in outflow tract defects, mainly Common Arterial Trunk (CAT).(Kodo and others 2009) Subsequent studies showed that GATA6 mutations also cause ASD and TOF.(Lin and others 2010) Like for GATA4, the mutational spectrum of GATA6 includes missense as well as truncating variants, and genotype-phenotype correlations are not established as the same mutation can cause different phenotypes. In many laboratories around the world, clinical genetic testing is commonly available for GATA4, but not for GATA6.

\subsection{Homeobox transcription factors (NKX2-5, NKX2-6)}

Homeobox-containing genes are transcription factors that play crucial roles in cardiac development through regulating essential processes such as the spatio-temporal specificity of gene expression required for normal cardiac tissue differentiation. This transcription factor is evolutionary conserved and essential for cardiac development. The "Tinman" gene in drosophila is a homeobox-containing gene that is essential for development of the dorsal vessel, a structure analogous to the human heart. NKX2-5 is the "Tinman" homologue in mouse and is highly expressed in the mouse embryologic heart and essential for its development.(Reamon-Buettner and Borlak 2010) The NKX2-5 gene was cloned in 1996 (Turbay and others 1996), and since then it was shown to be one of the most common known genetic causes of human CHD. 
NKX2-5 plays critical roles in later stages of cardiac development, namely septation and development of the conduction system. It physically interacts with TBX5 to form a complex that cooperatively regulates downstream gene expression that is essential for proper septation and formation of the conduction system.(Habets and others 2002; Moskowitz and others 2007) Mutations in NKX2-5 gene cause congenital heart disease in an autosomal dominant fashion and with high penetrance.(Kasahara and others 2000) Many families have been described. The most common phenotype is ASD with Atrioventricular (AV) Block. However NKX2-5 mutations have also been associated with many other CHD phenotypes such as VSD, TOF, subvalvar AS, Ebstein's Anomaly, cardiomyopathy, ventricular hypertrophy or non-compaction, and arrythmias other than the common $\mathrm{AV}$ block.(Reamon-Buettner and Borlak 2010) Also in families, different CHD phenotypes can be observed with the same NKX2-5 mutations making genotype-phenotype correlations difficult. In cohorts of isolated CHD, NKX2-5 mutations are found in around 2\%.(ReamonBuettner and Borlak 2010) The mutational spectrum is wide with missense and truncating mutations being heavily described. Sequencing for NKX2-5 is clinically available for genetic testing. Identifying family members through cascade screening might allow the diagnosis of fatal arrythmias or silent ASD's that can otherwise lead to heart failure.

NKX2-6 is another homeobox transcription factor that shares great homology with NKX2-6 but whose downstream targets are unknown. Mouse in which NKX2-6 was knocked out did not have any cardiac phenotype, but one mutation has been associated with CAT in one family.(Heathcote and others 2005) More mutations in NKX2-6 remain to be detected in CHD patients with high throughput screening before its causality to $\mathrm{CHD}$ could be established.

\subsection{T-Box transcription factors $(T B X 1, T B X 5, T B X 20)$}

The T-box family of binding proteins also consists of important transcription factors in cardiac development. T-box genes are evolutionary conserved and share a T-binding domain. All family members are involved in regulating developmental processes such as the initiation and potentiation of cardiac development.(Hariri and others 2011)

The crucial role of TBX5 in heart development and its interactions with GATA4 and NKX2-5 has been discussed earlier in this chapter. Apart from Holt-Oram Syndrome, TBX5 has not been implicated in nonsyndromic CHD, although some TBX5 mutations can cause a heartpredominant phenotype with very subtle upper limbs disease. TBX1 was also discussed earlier as the cause of cardiac malformations in Di George Syndrome. A large deletion of $57 \mathrm{bp}$ in the TBX1 gene was found in one non-syndromic patient with TOF.(Griffin and others 2010) Apart from this single report, findings of TBX1 mutations have not been duplicated in non-syndromic CHD patients.

Another member of the family that has been implicated in non-syndromic CHD is TBX20. $\mathrm{Tb} \times 20^{+-}$mice have dilated cardiomyopathy and TBX20-- mice die at midgestation due to grossly abnormal heart.(Stennard and others 2005) Mutations in TBX20 are found in less than $1 \%$ of patients with CHD phenotypes such as septal defects, left ventricular outflow 
tract abnormalities, and HLH syndrome.(Kirk and others 2007; Posch and others 2010) Both missense and nonsense heterozygous mutations are described. Functional studies suggest that both loss of function and gain of function mutations in the TBX20 gene can cause CHD.(Posch and others 2010)

\subsection{Other transcription factors (CITED2, ANKRD1, FOG2, ZIC3)}

The above three families of transcription factors are the most heavily studied in heart development, however a large set of other transcription factors have also been implicated in CHD, yet with lower degrees of evidence, or for some lower penetrance. This section will briefly discuss each of these transcription factors.

CITED2 codes for CBP/p300-Interacting Transactivator with E/D-rich c-terminal Domain Type 2, a transcriptional co-activator several transcriptional responses such as TFAP2, the known cause of Char Syndrome. CITED2 null mouse embryos die embryologically and manifest septal, outflow tract, and aortic arch defects.(Bamforth and others 2004) CITED2 mutations were detected in about $1 \%$ of sporadic cases of CHD. Phenotypes include ASD, VSD, and TAPVC.(Sperling and others 2005)

Ankyrin Repeat Domain 1 (ANKRD1) is a transcription factor that interacts with cardiac sarcomere proteins. One balanced translocation and one missense mutation in ANKRD1 gene were detected in two separate cases of TAPVC.(Cinquetti and others 2008)

Friend of GATA 2 (FOG2) is, as its name implies, a cofactor of GATA4. FOG2 knockout mice have TOF-like phenotype,(Tevosian and others 2000) and FOG2 mutations have been described in TOF patients however with reduced penetrance.(Pizzuti and others 2003)

ZIC3 encodes for a zinc finger transcription factor that is implicated in left-right axis development. It is a known gene in human situs abnormalities and is inherited in an Xlinked fashion. Mutations in ZIC3 have been identified in families and cohorts of heterotaxy.(Gebbia and others 1997) Additionally, there has been one reported family with TGA carrying a transversion in the ZIC3 gene, yet with incomplete penetrance.(Megarbane and others 2000)

\subsection{NODAL signaling genes (NODAL, GDF1, FOXH1, CFC1, ACVR2B, LEFTY2)}

The NODAL family of proteins is member of the TGF-beta superfamily of secreted signaling molecules. NODAL signaling is responsible for dorso-ventral patterning in vertebrate development as well as mesoderm and endoderm generation. Mutations in different genes in the NODAL signaling cascade are believed to occur and cumulatively decrease NODAL signaling leading to CHD phenotypes.(Roessler and others 2009) NODAL mutations have been reported in patients with heterotaxy, TGA, and conotruncal defects,(Gebbia and others 1997; Mohapatra and others 2009) but as mentioned earlier simple heterozygosity is not 
enough to cause the phenotype in the majority of cases. Mutations in other pathway genes such as GDF1, FOXH1, CFC1, and LEFTY2 are often necessary to cause disease.

CFC1 (Cryptic) is a cofactor of NODAL signaling and its acts through activin receptors. CFC1 mutations have been initially reported in laterality defects.(Bamford and others 2000) However, outflow tract defects such as TGA and DORV have also been associated with CFC1 mutations.(Goldmuntz and others 2002) Similar associations with CHD phenotypes apart from situs abnormalities have been observed for GDF1, another member of the TGFbeta superfamily involved in NODAL signaling.(Karkera and others 2007) FOXH1 mutations have been associated with CHD however only within the context of reduced NODAL signaling due to mutations in more than one gene in the cascade.(Roessler and others 2008) Therefore, sequencing of all NODAL signaling genes together would give a better picture of the genetic cause of a particular CHD phenotype rather than identifying a variant in one of the genes.

\subsection{Notch signaling genes (NOTCH1, JAG1, NOTCH2)}

The Notch-Jagged signaling pathway is an important regulatory mechanism of cell differentiation processes during embryonic and adult life. In the heart, it is particularly important in cardiac valve development. JAG1 and NOTCH2 mutations are known causes of Alagille Syndrome. However mutations in both can cause non-syndromic CHD.(Bauer and others 2010; McDaniell and others 2006) NOTCH1 has been also implicated in nonsyndromic CHD. Mutations can cause BAV, AS, COA, and HLH.(Garg and others 2005; McBride and others 2008; Mohamed and others 2006)

\subsection{Contractile protein genes (MYH6, MYH7, MYH11, MYBPC3, ACTC1)}

Mutations in contractile protein genes are common causes of Hypertrophic Cardiomyopathy (HCM) and other cardiomyopathies. However, some of these genes have also been implicated in a minority of CHD cases. One MYH6 (Alpha Myosin Heavy Chain) mutation has been described in a family with ASD. (Ching and others 2005) Mutations in MYH7 (Beta Myosin Heavy Chain) can cause Ebstein's Anomaly and septal defects.(Budde and others 2007) Heterozygous $M Y B P C 3$ mutations are a very frequent cause of HCM, however there have been reports of ASD and PDA in addition to severe HCM in patients with homozygous truncating mutations in the Myosin Binding Protein C gene MYBPC3.(Xin and others 2007; Zahka and others 2008) Similarly, mutations in Alpha-Cardiac Actin ACTC1, another sarcomere protein gene, cause ASD together with HCM.(Monserrat and others 2007) Finally, Myosin Heavy Chain 11 (MYH11) has a role in smooth muscles, and mutations in MYH11 have been implicated in familial thoracic aortic aneurysm with PDA due to decreased elasticity of the aortic wall and the ductus arteriosus.(Zhu and others 2006)

\subsection{Miscellaneous genes (ELN, GJA1, FLNA, THRAP2)}

Elastin (ELN) deletion or mutations are implicated in Williams-Beuren syndrome, however have also been reported in many cases of isolated SVAS and PS. (Arrington and others 2006; 
Metcalfe and others 2000) GJA1 encodes Connexin-43, a gap junction protein that maintains cell-cell adhesion and communication. Mutations in GJA1 were reported in a case of HLH and another report of heterotaxia patients. (Britz-Cunningham and others 1995; Dasgupta and others 2001) Filamin A (FLNA) cross-links actin filaments in the cytoplasm and anchors them to the rest of the cytoskeleton. FLNA is an X-linked gene in which mutations are associated with valvular dystrophy. (Kyndt and others 2007) Finally, mutations in the THRAP2 gene, which encodes a TRAP-complex protein, have been associated with TGA in one study.(Muncke and others 2003)

\section{Other genetic mechanisms of CHD}

Despite the large number of genes implicated in non-syndromic CHD, the genetic cause of the majority of isolated cases of CHD is still poorly understood. This has led researchers to investigate genetic mechanisms other than gene mutations that can contribute to inherited or isolated CHD. Copy Number Variations (CNVs), micro RNA (miRNA), somatic mutations, and epigenetics are all active areas of research into the genetics of CHD.

\subsection{Copy Number Variations}

Copy Number Variations (CNVs) are structural alterations to the genomic DNA that result in the cell having abnormal copies of large sections of its DNA. They can be inherited or occur de novo. Over the past decade, the role of CNVs in disease has been heavily studied, mostly in different types of cancers. In the heart, CNV analysis has explained an additional small fraction of the genetics of syndromic CHD (3.6\%), but more of the non-syndromic CHD (19\%).(Breckpot and others 2011) Submicroscopic deletions have been discovered using array-CGH in large $\mathrm{CHD}$ cohorts. $\mathrm{CNV}$ s occured in regions harboring known CHD candidate genes but were also capable of identifying new $\mathrm{CHD}$ loci in TOF, HLH, heterotaxy, and other CHD phenotypes.(Fakhro and others 2011; Greenway and others 2009; Payne and others 2012) One of the most commonly used strategies in CNV analysis is trio analysis, which allows the determination of de novo $\mathrm{CNVs}$ in CHD patients. Comparison with control groups is also helpful in assessing the likelihood of causality of CNVs using statistical methods. Despite several successful examples, the use of CNVs in understanding CHD remains challenging, particularly in proving the causality of the CNVs and assessing the magnitude that these CNVs have on the phenotype.

\subsection{Micro RNA}

Micro RNAs (miRNAs) are small (around 22 nucleotides long) single stranded noncoding RNAs and are encoded by miRNA genes. miRNAs serve as regulators of gene expression. Since cardiac development involves tremendous spatio-temportal specificity of gene expression, it is believed that miRNAs are involved in cardiac development and they can potentially cause CHD. miRNAs are important players in cellular proliferation, differentiation, and migration all of which are essential processes for proper cardiac 
development. In fact, cardiac specific miRNAs were discovered such as miR-133 and miR-12 , both of which when knocked out in mice cause cardiac defects, specifically VSD and dilated cardiomyopathy.(Ikeda and others 2007) miR-208a and miR-208b are also cardiacenriched, and they are encoded within the introns of MYH6 and MYH7.(Callis and others 2009; van Rooij and others 2007) Current research focuses on sequencing miRNA to identify potential mutations that can cause CHD. Definite evidence in humans is still unavailable but might be underway.

\subsection{Somatic mutations}

Another direction of research to assess CHD is the study of somatic mutations using surgically discarded tissues from CHD patients who undergo surgical repair. Both DNA and RNA can be extracted and sequenced. Previous studies have focused on sequencing GATA4 and Nkx2-5 in somatic DNA of patients with septal defects, and yielded controversial findings as to whether somatic mutations contribute significantly to these genes.(Draus and others 2009; Esposito and others 2011; Reamon-Buettner and Borlak 2004) In the current era of high throughput DNA sequencing, and development of new analytical frameworks for RNA sequencing, the contribution of somatic mutations to CHD will become clearer soon, however no significant data in this field is published yet.

\subsection{Epigenetics}

The multifactorial causality of CHD has long been hypothesized to explain the complexity of the genetics of cardiac malformations. Epigenetics is one model where gene-environment interaction can affect gene expression and disturb developmental processes in the embryonic heart. Histone modifications and chromatin remodeling both play important roles in cardiac development and physiology(Han and others 2011; Lange and others 2008; Ohtani and Dimmeler 2011), and recent studies shoed that they can directly interact with some classes of transcription factors like the T-box family.(Miller and Weinmann 2009) It is possible that epigenetic mechanisms contribute to the etiology of $\mathrm{CHD}$, however more evidence remains to be established.

\section{Current tools for the genetic evaluation of CHD}

Different techniques are currently available to interrogate the genetic causes of CHD. Karyotyping and Fluorescent In-Situ Hybridization (FISH) analysis remain the best tools to assess chromosomal deletions or rearrangements. They are often the starting point for the genetic assessment of a CHD patient. Whenever candidate genes are suspected, for instance in the setting of a clinically diagnosed syndrome, Sanger sequencing is performed on the candidate gene to look for disease-causing mutations. For many years, together with positional mapping through linkage analysis, these were the only tools that drove genetic discovery in CHD in humans. Current technology makes use of array-comparative genomic hybridization (array-CGH) for linkage analysis, Genome Wide Association Studies (GWAS), CNV analysis, homozygosity mapping, and transcriptome analysis. More 
importantly was the introduction of next-generation sequencing in 2005 and the tremendous decrease in the cost of sequencing over the past several years, which is allowing the massive sequencing of the exome and even genome of huge numbers of patients. Next-generation RNA sequencing is also beginning to be used to sequence cardiac transcripts from CHD patients who have underwent surgery. The rapid pooling of high throughput data is expected to massively increase our understanding of CHD within the coming two years. To deal with these large amounts of data, bioinformatics and modeling of genetic variants determine function is becoming the standard and many molecular biology labs are forced to become genetics and bioinformatics labs to make use of current technology. A systems biology approach is needed nowadays to integrate high throughput data from the many possible sources.

\section{From the bench to the bedside}

With the advances in sequencing and bioinformatics, gene discovery in CHD is escalating. This advance in research is directly translated to clinical testing to provide genetic counseling for adult patients with CHD who plan to have children. From a technical aspect, our capability to identify genetic variants in CHD genes has magnified. Nonetheless, making functional significance and even clinical sense of the large number of gene mutations remains a big challenge. Given the complexity of $\mathrm{CHD}$, definite gene mutations remain uncommon. At this time when the genetic inflow of information is very fast, physician-scientists must be very careful in communicating genetic information that is not validated to patients, in order to avoid psychological and emotional harm. On a different angle, with sequencing of the exome or genome, the chances of detecting incidental findings that indicate disease risk or prognosis becomes very high. All such unintentionally detected serious genetic findings are termed the incidentalome.(Kohane and others 2006) Since CHD is mostly surgically treated and people who undergo genetic testing are often already cured, caregivers need to be cautious before rushing next-generation sequencing into the $\mathrm{CHD}$ clinic.

\section{Future prospects}

Current trends in CHD genetics research are making use of the rapidly developing technology, particularly high throughput sequencing. This trend will continue over the coming few years. The challenge is in integrating the increasing amounts of data to answer the questions that need to be answered. Systems biology and innovative bioinformatics tools are crucial to integrate data from different sources and build a pipeline that can unravel the mysteries that molecular biologists have been trying to answer for many years.

Eventually, more validated genetic information will be available in the clinic to allow accurate genetic counseling and prenatal screening. Understanding heart development will also allow for possible therapeutic applications given the many-shared molecular pathways between embryologic heart development and adult heart disease, particularly tissue death and regeneration in the setting of ischemic heart disease. 


\section{Author details}

Akl C. Fahed

Department of Genetics, Harvard Medical School, Boston, Massachusetts, USA

Georges M. Nemer

Departent of Biochemistry and Molecular Genetics, American University of Beirut, Beirut, Lebanon

\section{References}

Arrington CB, Nightengale D, Lowichik A, Rosenthal ET, Christian-Ritter K, Viskochil DH. (2006). Pathologic and molecular analysis in a family with rare mixed supravalvar aortic and pulmonic stenosis. Pediatr Dev Pathol 9,297-306.

Bamford RN, Roessler E, Burdine RD, Saplakoglu U, dela Cruz J, Splitt M, Goodship JA, Towbin J, Bowers P, Ferrero GB and others. (2000). Loss-of-function mutations in the EGF-CFC gene CFC1 are associated with human left-right laterality defects. Nat Genet 26,365-9.

Bamforth SD, Braganca J, Farthing CR, Schneider JE, Broadbent C, Michell AC, Clarke K, Neubauer S, Norris D, Brown NA and others. (2004). Cited2 controls left-right patterning and heart development through a Nodal-Pitx2c pathway. Nat Genet 36,118996.

Basson CT, Bachinsky DR, Lin RC, Levi T, Elkins JA, Soults J, Grayzel D, Kroumpouzou E, Traill TA, Leblanc-Straceski J and others. (1997). Mutations in human TBX5 [corrected] cause limb and cardiac malformation in Holt-Oram syndrome. Nat Genet 15,30-5.

Basson CT, Cowley GS, Solomon SD, Weissman B, Poznanski AK, Traill TA, Seidman JG, Seidman CE. (1994). The clinical and genetic spectrum of the Holt-Oram syndrome (heart-hand syndrome). N Engl J Med 330,885-91.

Basson CT, Huang T, Lin RC, Bachinsky DR, Weremowicz S, Vaglio A, Bruzzone R, Quadrelli R, Lerone M, Romeo G and others. (1999). Different TBX5 interactions in heart and limb defined by Holt-Oram syndrome mutations. Proc Natl Acad Sci U S A 96,2919-24.

Bauer RC, Laney AO, Smith R, Gerfen J, Morrissette JJ, Woyciechowski S, Garbarini J, Loomes KM, Krantz ID, Urban Z and others. (2010). Jagged1 (JAG1) mutations in patients with tetralogy of Fallot or pulmonic stenosis. Hum Mutat 31,594-601.

Beuren AJ, Apitz J, Harmjanz D. (1962). Supravalvular aortic stenosis in association with mental retardation and a certain facial appearance. Circulation 26,1235-40.

Boehme DH, Shotar AO. (1989). A complex deformity of appendicular skeleton and shoulder with congenital heart disease in three generations of a Jordanian family. Clin Genet 36,442-50.

Bondy CA. (2009). Turner syndrome 2008. Horm Res 71 Suppl 1,52-6.

Breckpot J, Thienpont B, Arens Y, Tranchevent LC, Vermeesch JR, Moreau Y, Gewillig M, Devriendt K. (2011). Challenges of interpreting copy number variation in 
syndromic and non-syndromic congenital heart defects. Cytogenet Genome Res 135, 251-9.

Britz-Cunningham SH, Shah MM, Zuppan CW, Fletcher WH. (1995). Mutations of the Connexin43 gap-junction gene in patients with heart malformations and defects of laterality. N Engl J Med 332,1323-9.

Bruneau BG. (2008). The developmental genetics of congenital heart disease. Nature 451,9438.

Budde BS, Binner P, Waldmuller S, Hohne W, Blankenfeldt W, Hassfeld S, Bromsen J, Dermintzoglou A, Wieczorek M, May E and others. (2007). Noncompaction of the ventricular myocardium is associated with a de novo mutation in the beta-myosin heavy chain gene. PLoS One 2,e1362.

Callis TE, Pandya K, Seok HY, Tang RH, Tatsuguchi M, Huang ZP, Chen JF, Deng Z, Gunn B, Shumate J and others. (2009). MicroRNA-208a is a regulator of cardiac hypertrophy and conduction in mice. J Clin Invest 119,2772-86.

Chen Y, Han ZQ, Yan WD, Tang CZ, Xie JY, Chen H, Hu DY. (2010). A novel mutation in GATA4 gene associated with dominant inherited familial atrial septal defect. J Thorac Cardiovasc Surg 140,684-7.

Ching YH, Ghosh TK, Cross SJ, Packham EA, Honeyman L, Loughna S, Robinson TE, Dearlove AM, Ribas G, Bonser AJ and others. (2005). Mutation in myosin heavy chain 6 causes atrial septal defect. Nat Genet 37,423-8.

Cinquetti R, Badi I, Campione M, Bortoletto E, Chiesa G, Parolini C, Camesasca C, Russo A, Taramelli R, Acquati F. (2008). Transcriptional deregulation and a missense mutation define ANKRD1 as a candidate gene for total anomalous pulmonary venous return. Hum Mutat 29,468-74.

Curran ME, Atkinson DL, Ewart AK, Morris CA, Leppert MF, Keating MT. (1993). The elastin gene is disrupted by a translocation associated with supravalvular aortic stenosis. Cell 73,159-68.

Danks DM, Campbell PE, Jack I, Rogers J, Smith AL. (1977). Studies of the aetiology of neonatal hepatitis and biliary atresia. Arch Dis Child 52,360-7.

Dasgupta C, Martinez AM, Zuppan CW, Shah MM, Bailey LL, Fletcher WH. (2001). Identification of connexin43 (alpha1) gap junction gene mutations in patients with hypoplastic left heart syndrome by denaturing gradient gel electrophoresis (DGGE). Mutat Res 479,173-86.

Delabar JM, Theophile D, Rahmani Z, Chettouh Z, Blouin JL, Prieur M, Noel B, Sinet PM. (1993). Molecular mapping of twenty-four features of Down syndrome on chromosome 21. Eur J Hum Genet 1,114-24.

Doswell BH, Visootsak J, Brady AN, Graham JM, Jr. (2006). Turner syndrome: an update and review for the primary pediatrician. Clin Pediatr (Phila) 45,301-13.

Draus JM, Jr., Hauck MA, Goetsch M, Austin EH, 3rd, Tomita-Mitchell A, Mitchell ME. (2009). Investigation of somatic NKX2-5 mutations in congenital heart disease. J Med Genet 46,115-22. 
El-Rassy I, Bou-Abdallah J, Al-Ghadban S, Bitar F, Nemer G. (2008). Absence of NOTCH2 and Hey2 mutations in a familial Alagille syndrome case with a novel frameshift mutation in JAG1. Am J Med Genet A 146,937-9.

Emanuel BS. (2008). Molecular mechanisms and diagnosis of chromosome 22q11.2 rearrangements. Dev Disabil Res Rev 14,11-8.

Esposito G, Butler TL, Blue GM, Cole AD, Sholler GF, Kirk EP, Grossfeld P, Perryman BM, Harvey RP, Winlaw DS. (2011). Somatic mutations in NKX2-5, GATA4, and HAND1 are not a common cause of tetralogy of Fallot or hypoplastic left heart. Am J Med Genet A 155A,2416-21.

Fakhro KA, Choi M, Ware SM, Belmont JW, Towbin JA, Lifton RP, Khokha MK, Brueckner M. (2011). Rare copy number variations in congenital heart disease patients identify unique genes in left-right patterning. Proc Natl Acad Sci U S A 108,2915-20.

Garg V, Kathiriya IS, Barnes R, Schluterman MK, King IN, Butler CA, Rothrock CR, Eapen RS, Hirayama-Yamada K, Joo K and others. (2003). GATA4 mutations cause human congenital heart defects and reveal an interaction with TBX5. Nature 424, 443-7.

Garg V, Muth AN, Ransom JF, Schluterman MK, Barnes R, King IN, Grossfeld PD, Srivastava D. (2005). Mutations in NOTCH1 cause aortic valve disease. Nature 437,2704.

Gebbia M, Ferrero GB, Pilia G, Bassi MT, Aylsworth A, Penman-Splitt M, Bird LM, Bamforth JS, Burn J, Schlessinger D and others. (1997). X-linked situs abnormalities result from mutations in ZIC3. Nat Genet 17,305-8.

Gill HK, Splitt M, Sharland GK, Simpson JM. (2003). Patterns of recurrence of congenital heart disease: an analysis of 6,640 consecutive pregnancies evaluated by detailed fetal echocardiography. J Am Coll Cardiol 42,923-9.

Goldmuntz E. (2001). The epidemiology and genetics of congenital heart disease. Clin Perinatol 28,1-10.

Goldmuntz E, Bamford R, Karkera JD, dela Cruz J, Roessler E, Muenke M. (2002). CFC1 mutations in patients with transposition of the great arteries and double-outlet right ventricle. Am J Hum Genet 70,776-80.

Greenway SC, Pereira AC, Lin JC, DePalma SR, Israel SJ, Mesquita SM, Ergul E, Conta JH, Korn JM, McCarroll SA and others. (2009). De novo copy number variants identify new genes and loci in isolated sporadic tetralogy of Fallot. Nat Genet 41,931-5.

Griffin HR, Topf A, Glen E, Zweier C, Stuart AG, Parsons J, Peart I, Deanfield J, O'Sullivan J, Rauch A and others. (2010). Systematic survey of variants in TBX1 in non-syndromic tetralogy of Fallot identifies a novel 57 base pair deletion that reduces transcriptional activity but finds no evidence for association with common variants. Heart 96, 1651-5.

Grimm T, Wesselhoeft H. (1980). [The genetic aspects of Williams-Beuren syndrome and the isolated form of the supravalvular aortic stenosis. Investigation of 128 families (author's transl)]. Z Kardiol 69,168-72.

Habets PE, Moorman AF, Clout DE, van Roon MA, Lingbeek M, van Lohuizen M, Campione M, Christoffels VM. (2002). Cooperative action of Tbx2 and Nkx2.5 inhibits 
ANF expression in the atrioventricular canal: implications for cardiac chamber formation. Genes Dev 16,1234-46.

Hamada T, Gejyo F, Koshino Y, Murata T, Omori M, Nishio M, Misawa T, Isaki K. (1998). Echocardiographic evaluation of cardiac valvular abnormalities in adults with Down's syndrome. Tohoku J Exp Med 185,31-5.

Han P, Hang CT, Yang J, Chang CP. (2011). Chromatin remodeling in cardiovascular development and physiology. Circ Res 108,378-96.

Hariri F, Nemer M, Nemer G. (2011). T-box factors: Insights into the evolutionary emergence of the complex heart. Ann Med.

Heathcote K, Braybrook C, Abushaban L, Guy M, Khetyar ME, Patton MA, Carter ND, Scambler PJ, Syrris P. (2005). Common arterial trunk associated with a homeodomain mutation of NKX2.6. Hum Mol Genet 14,585-93.

Herrera P, Caldarone CA, Forte V, Holtby H, Cox P, Chiu P, Kim PC. (2008). Topsy-turvy heart with associated congenital tracheobronchial stenosis and airway compression requiring surgical reconstruction. Ann Thorac Surg 86,282-3.

Ikeda S, Kong SW, Lu J, Bisping E, Zhang H, Allen PD, Golub TR, Pieske B, Pu WT. (2007). Altered microRNA expression in human heart disease. Physiol Genomics 31,36773.

Jaeggi E, Chitayat D, Golding F, Kim P, Yoo SJ. (2008). Prenatal diagnosis of topsy-turvy heart. Cardiol Young 18,337-42.

Kamath BM, Podkameni G, Hutchinson AL, Leonard LD, Gerfen J, Krantz ID, Piccoli DA, Spinner NB, Loomes KM, Meyers K. (2011). Renal anomalies in Alagille syndrome: A disease-defining feature. Am J Med Genet A.

Karkera JD, Lee JS, Roessler E, Banerjee-Basu S, Ouspenskaia MV, Mez J, Goldmuntz E, Bowers P, Towbin J, Belmont JW and others. (2007). Loss-of-function mutations in growth differentiation factor-1 (GDF1) are associated with congenital heart defects in humans. Am J Hum Genet 81,987-94.

Kasahara H, Lee B, Schott JJ, Benson DW, Seidman JG, Seidman CE, Izumo S. (2000). Loss of function and inhibitory effects of human CSX/NKX2.5 homeoprotein mutations associated with congenital heart disease. J Clin Invest 106,299-308.

Kirk EP, Sunde M, Costa MW, Rankin SA, Wolstein O, Castro ML, Butler TL, Hyun C, Guo G, Otway R and others. (2007). Mutations in cardiac T-box factor gene TBX20 are associated with diverse cardiac pathologies, including defects of septation and valvulogenesis and cardiomyopathy. Am J Hum Genet 81,280-91.

Kodo K, Nishizawa T, Furutani M, Arai S, Yamamura E, Joo K, Takahashi T, Matsuoka R, Yamagishi H. (2009). GATA6 mutations cause human cardiac outflow tract defects by disrupting semaphorin-plexin signaling. Proc Natl Acad Sci U S A 106,139338.

Kohane IS, Masys DR, Altman RB. (2006). The incidentalome: a threat to genomic medicine. JAMA 296,212-5.

Korenberg JR, Chen XN, Schipper R, Sun Z, Gonsky R, Gerwehr S, Carpenter N, Daumer C, Dignan P, Disteche C and others. (1994). Down syndrome phenotypes: 
the consequences of chromosomal imbalance. Proc Natl Acad Sci U S A 91,49975001.

Kyndt F, Gueffet JP, Probst V, Jaafar P, Legendre A, Le Bouffant F, Toquet C, Roy E, McGregor L, Lynch SA and others. (2007). Mutations in the gene encoding filamin A as a cause for familial cardiac valvular dystrophy. Circulation 115,40-9.

Lange M, Kaynak B, Forster UB, Tonjes M, Fischer JJ, Grimm C, Schlesinger J, Just S, Dunkel I, Krueger T and others. (2008). Regulation of muscle development by DPF3, a novel histone acetylation and methylation reader of the BAF chromatin remodeling complex. Genes Dev 22,2370-84.

Lepore JJ, Mericko PA, Cheng L, Lu MM, Morrisey EE, Parmacek MS. (2006). GATA-6 regulates semaphorin $3 \mathrm{C}$ and is required in cardiac neural crest for cardiovascular morphogenesis. J Clin Invest 116,929-39.

Li L, Krantz ID, Deng Y, Genin A, Banta AB, Collins CC, Qi M, Trask BJ, Kuo WL, Cochran J and others. (1997a). Alagille syndrome is caused by mutations in human Jagged1, which encodes a ligand for Notch1. Nat Genet 16,243-51.

Li QY, Newbury-Ecob RA, Terrett JA, Wilson DI, Curtis AR, Yi CH, Gebuhr T, Bullen PJ, Robson SC, Strachan T and others. (1997b). Holt-Oram syndrome is caused by mutations in TBX5, a member of the Brachyury $(\mathrm{T})$ gene family. Nat Genet 15, 21-9.

Lin X, Huo Z, Liu X, Zhang Y, Li L, Zhao H, Yan B, Liu Y, Yang Y, Chen YH. (2010). A novel GATA6 mutation in patients with tetralogy of Fallot or atrial septal defect. J Hum Genet 55,662-7.

Loffredo CA. (2000). Epidemiology of cardiovascular malformations: prevalence and risk factors. Am J Med Genet 97,319-25.

Lopez L, Arheart KL, Colan SD, Stein NS, Lopez-Mitnik G, Lin AE, Reller MD, Ventura R, Silberbach M. (2008). Turner syndrome is an independent risk factor for aortic dilation in the young. Pediatrics 121,e1622-7.

Marino B. (1993). Congenital heart disease in patients with Down's syndrome: anatomic and genetic aspects. Biomed Pharmacother 47,197-200.

Marino B, Digilio MC, Toscano A, Giannotti A, Dallapiccola B. (1999). Congenital heart diseases in children with Noonan syndrome: An expanded cardiac spectrum with high prevalence of atrioventricular canal. J Pediatr 135,703-6.

Maslen CL, Babcock D, Robinson SW, Bean LJ, Dooley KJ, Willour VL, Sherman SL. (2006). CRELD1 mutations contribute to the occurrence of cardiac atrioventricular septal defects in Down syndrome. Am J Med Genet A 140,2501-5.

McBride KL, Riley MF, Zender GA, Fitzgerald-Butt SM, Towbin JA, Belmont JW, Cole SE. (2008). NOTCH1 mutations in individuals with left ventricular outflow tract malformations reduce ligand-induced signaling. Hum Mol Genet 17,2886-93.

McDaniell R, Warthen DM, Sanchez-Lara PA, Pai A, Krantz ID, Piccoli DA, Spinner NB. (2006). NOTCH2 mutations cause Alagille syndrome, a heterogeneous disorder of the notch signaling pathway. Am J Hum Genet 79,169-73.

McElhinney DB, Krantz ID, Bason L, Piccoli DA, Emerick KM, Spinner NB, Goldmuntz E. (2002). Analysis of cardiovascular phenotype and genotype-phenotype correlation in 
individuals with a JAG1 mutation and/or Alagille syndrome. Circulation 106,256774.

Megarbane A, Salem N, Stephan E, Ashoush R, Lenoir D, Delague V, Kassab R, Loiselet J, Bouvagnet P. (2000). X-linked transposition of the great arteries and incomplete penetrance among males with a nonsense mutation in ZIC3. Eur J Hum Genet 8, 704-8.

Metcalfe K, Rucka AK, Smoot L, Hofstadler G, Tuzler G, McKeown P, Siu V, Rauch A, Dean J, Dennis N and others. (2000). Elastin: mutational spectrum in supravalvular aortic stenosis. Eur J Hum Genet 8,955-63.

Miller SA, Weinmann AS. (2009). An essential interaction between T-box proteins and histone-modifying enzymes. Epigenetics 4,85-8.

Mohamed SA, Aherrahrou Z, Liptau H, Erasmi AW, Hagemann C, Wrobel S, Borzym K, Schunkert H, Sievers HH, Erdmann J. (2006). Novel missense mutations (p.T596M and p.P1797H) in NOTCH1 in patients with bicuspid aortic valve. Biochem Biophys Res Commun 345,1460-5.

Mohapatra B, Casey B, Li H, Ho-Dawson T, Smith L, Fernbach SD, Molinari L, Niesh SR, Jefferies JL, Craigen WJ and others. (2009). Identification and functional characterization of NODAL rare variants in heterotaxy and isolated cardiovascular malformations. Hum Mol Genet 18,861-71.

Momma K. (2010). Cardiovascular anomalies associated with chromosome 22q11.2 deletion syndrome. Am J Cardiol 105,1617-24.

Monserrat L, Hermida-Prieto M, Fernandez X, Rodriguez I, Dumont C, Cazon L, Cuesta MG, Gonzalez-Juanatey C, Peteiro J, Alvarez N and others. (2007). Mutation in the alpha-cardiac actin gene associated with apical hypertrophic cardiomyopathy, left ventricular non-compaction, and septal defects. Eur Heart J 28,1953-61.

Moodie DS. (1994). Adult congenital heart disease. Curr Opin Cardiol 9,137-42.

Moskowitz IP, Kim JB, Moore ML, Wolf CM, Peterson MA, Shendure J, Nobrega MA, Yokota Y, Berul C, Izumo S and others. (2007). A molecular pathway including Id2, Tbx5, and Nkx2-5 required for cardiac conduction system development. Cell 129,136576.

Muncke N, Jung C, Rudiger H, Ulmer H, Roeth R, Hubert A, Goldmuntz E, Driscoll D, Goodship J, Schon K and others. (2003). Missense mutations and gene interruption in PROSIT240, a novel TRAP240-like gene, in patients with congenital heart defect (transposition of the great arteries). Circulation 108,2843-50.

Nemer G, Fadlalah F, Usta J, Nemer M, Dbaibo G, Obeid M, Bitar F. (2006). A novel mutation in the GATA4 gene in patients with Tetralogy of Fallot. Hum Mutat 27,293-4.

Noonan JA. (1994). Noonan syndrome. An update and review for the primary pediatrician. Clin Pediatr (Phila) 33,548-55.

Oda T, Elkahloun AG, Pike BL, Okajima K, Krantz ID, Genin A, Piccoli DA, Meltzer PS, Spinner NB, Collins FS and others. (1997). Mutations in the human Jagged1 gene are responsible for Alagille syndrome. Nat Genet 16,235-42.

Ohtani K, Dimmeler S. (2011). Epigenetic regulation of cardiovascular differentiation. Cardiovasc Res 90,404-12. 
Payne AR, Chang SW, Koenig SN, Zinn AR, Garg V. (2012). Submicroscopic Chromosomal Copy Number Variations Identified in Children With Hypoplastic Left Heart Syndrome. Pediatr Cardiol.

Peng T, Wang L, Zhou SF, Li X. (2010). Mutations of the GATA4 and NKX2.5 genes in Chinese pediatric patients with non-familial congenital heart disease. Genetica $138,1231-40$.

Pizzuti A, Sarkozy A, Newton AL, Conti E, Flex E, Digilio MC, Amati F, Gianni D, Tandoi C, Marino B and others. (2003). Mutations of ZFPM2/FOG2 gene in sporadic cases of tetralogy of Fallot. Hum Mutat 22,372-7.

Pober BR. (2010). Williams-Beuren syndrome. N Engl J Med 362,239-52.

Pober BR, Johnson M, Urban Z. (2008). Mechanisms and treatment of cardiovascular disease in Williams-Beuren syndrome. J Clin Invest 118,1606-15.

Posch MG, Gramlich M, Sunde M, Schmitt KR, Lee SH, Richter S, Kersten A, Perrot A, Panek AN, Al Khatib IH and others. (2010). A gain-of-function TBX20 mutation causes congenital atrial septal defects, patent foramen ovale and cardiac valve defects. J Med Genet 47,230-5.

Pueschel SM. (1990). Clinical aspects of Down syndrome from infancy to adulthood. Am J Med Genet Suppl 7,52-6.

Rajagopal SK, Ma Q, Obler D, Shen J, Manichaikul A, Tomita-Mitchell A, Boardman K, Briggs C, Garg V, Srivastava D and others. (2007). Spectrum of heart disease associated with murine and human GATA4 mutation. J Mol Cell Cardiol 43,677-85.

Reamon-Buettner SM, Borlak J. (2004). Somatic NKX2-5 mutations as a novel mechanism of disease in complex congenital heart disease. J Med Genet 41,684-90.

Reamon-Buettner SM, Borlak J. (2010). NKX2-5: an update on this hypermutable homeodomain protein and its role in human congenital heart disease (CHD). Hum Mutat 31,1185-94.

Roessler E, Ouspenskaia MV, Karkera JD, Velez JI, Kantipong A, Lacbawan F, Bowers P, Belmont JW, Towbin JA, Goldmuntz E and others. (2008). Reduced NODAL signaling strength via mutation of several pathway members including FOXH1 is linked to human heart defects and holoprosencephaly. Am J Hum Genet 83,18-29.

Roessler E, Pei W, Ouspenskaia MV, Karkera JD, Velez JI, Banerjee-Basu S, Gibney G, Lupo PJ, Mitchell LE, Towbin JA and others. (2009). Cumulative ligand activity of NODAL mutations and modifiers are linked to human heart defects and holoprosencephaly. Mol Genet Metab 98,225-34.

Sperling S, Grimm CH, Dunkel I, Mebus S, Sperling HP, Ebner A, Galli R, Lehrach H, Fusch C, Berger F and others. (2005). Identification and functional analysis of CITED2 mutations in patients with congenital heart defects. Hum Mutat 26,575-82.

Stennard FA, Costa MW, Lai D, Biben C, Furtado MB, Solloway MJ, McCulley DJ, Leimena C, Preis JI, Dunwoodie SL and others. (2005). Murine T-box transcription factor Tbx20 acts as a repressor during heart development, and is essential for adult heart integrity, function and adaptation. Development 132,2451-62.

Stromme P, Bjornstad PG, Ramstad K. (2002). Prevalence estimation of Williams syndrome. J Child Neurol 17,269-71. 
Tartaglia M, Zampino G, Gelb BD. (2010). Noonan syndrome: clinical aspects and molecular pathogenesis. Mol Syndromol 1,2-26.

Tevosian SG, Deconinck AE, Tanaka M, Schinke M, Litovsky SH, Izumo S, Fujiwara Y, Orkin SH. (2000). FOG-2, a cofactor for GATA transcription factors, is essential for heart morphogenesis and development of coronary vessels from epicardium. Cell 101, 729-39.

Tidyman WE, Rauen KA. (2009). The RASopathies: developmental syndromes of Ras/MAPK pathway dysregulation. Curr Opin Genet Dev 19,230-6.

Tomita-Mitchell A, Maslen CL, Morris CD, Garg V, Goldmuntz E. (2007). GATA4 sequence variants in patients with congenital heart disease. J Med Genet 44,779-83.

Turbay D, Wechsler SB, Blanchard KM, Izumo S. (1996). Molecular cloning, chromosomal mapping, and characterization of the human cardiac-specific homeobox gene hCsx. Mol Med 2,86-96.

van der Bom T, Zomer AC, Zwinderman AH, Meijboom FJ, Bouma BJ, Mulder BJ. (2011). The changing epidemiology of congenital heart disease. Nat Rev Cardiol 8, 50-60.

van Rooij E, Sutherland LB, Qi X, Richardson JA, Hill J, Olson EN. (2007). Control of stressdependent cardiac growth and gene expression by a microRNA. Science 316,575-9.

Williams JC, Barratt-Boyes BG, Lowe JB. (1961). Supravalvular aortic stenosis. Circulation 24,1311-8.

Xin B, Puffenberger E, Tumbush J, Bockoven JR, Wang H. (2007). Homozygosity for a novel splice site mutation in the cardiac myosin-binding protein $C$ gene causes severe neonatal hypertrophic cardiomyopathy. Am J Med Genet A 143A,2662-7.

Xin M, Davis CA, Molkentin JD, Lien CL, Duncan SA, Richardson JA, Olson EN. (2006). A threshold of GATA4 and GATA6 expression is required for cardiovascular development. Proc Natl Acad Sci U S A 103,11189-94.

Yagi H, Furutani Y, Hamada H, Sasaki T, Asakawa S, Minoshima S, Ichida F, Joo K, Kimura M, Imamura $S$ and others. (2003). Role of TBX1 in human del22q11.2 syndrome. Lancet 362,1366-73.

Yuan ZR, Kohsaka T, Ikegaya T, Suzuki T, Okano S, Abe J, Kobayashi N, Yamada M. (1998). Mutational analysis of the Jagged 1 gene in Alagille syndrome families. Hum Mol Genet 7,1363-9.

Zahka K, Kalidas K, Simpson MA, Cross H, Keller BB, Galambos C, Gurtz K, Patton MA, Crosby AH. (2008). Homozygous mutation of MYBPC3 associated with severe infantile hypertrophic cardiomyopathy at high frequency among the Amish. Heart 94,132630.

Zhang L, Tumer Z, Jacobsen JR, Andersen PS, Tommerup N, Larsen LA. (2006). Screening of 99 Danish patients with congenital heart disease for GATA4 mutations. Genet Test 10,277-80.

Zhao R, Watt AJ, Battle MA, Li J, Bondow BJ, Duncan SA. (2008). Loss of both GATA4 and GATA6 blocks cardiac myocyte differentiation and results in acardia in mice. Dev Biol 317,614-9. 
Zhu L, Vranckx R, Khau Van Kien P, Lalande A, Boisset N, Mathieu F, Wegman M, Glancy L, Gasc JM, Brunotte F and others. (2006). Mutations in myosin heavy chain 11 cause a syndrome associating thoracic aortic aneurysm/aortic dissection and patent ductus arteriosus. Nat Genet 38,343-9. 